\title{
Conjunctival Melanoma pT4 TNM Finding v8
}

National Cancer Institute

\section{Source}

National Cancer Institute. Conjunctival Melanoma pT4 TNM Finding v8. NCI Thesaurus.

Code C140598.

Conjunctival melanoma with tumor of any size invading the central nervous system.

(from AJCC 8th Ed.) 